\title{
OPINION
}

\section{Do We Want 'More or Fewer' Prosecutions of Opinions? The Geert Wilders Trial 2.0*}

\author{
Jogchum Vrielink
}

To what extent should we tolerate the intolerant? This age-old question in legal theory has been tested on a daily basis by provocateur par excellence Geert Wilders, leader of the Party for Freedom (Partij voor de Vrijheid).

Wilders was convicted by a panel of three judges on 9 December 2016, in the first round of the second hate speech trial against him. ${ }^{1}$

What exactly had Wilders said, to merit prosecution? The trial concerned two sets of remarks made in The Hague around the time of the Dutch municipal elections in 2014. Firstly, during a campaign visit to a suburb of The Hague on 12 March 2014, Wilders said that a vote for his party would amount to a vote for 'a safer and more social city, with less expenses and, if possible, fewer Moroccans'. A week later, on the eve of the elections, Wilders asked a cafe filled with supporters whether they wanted 'more or fewer Moroccans'. The crowd chanted, 'Fewer, fewer, fewer!' to which Wilders responded: 'Well, then we'll arrange that'.

The public prosecution instigated criminal proceedings after police received some 6,000 complaints in response to Wilders's statements. The politician was charged with 'group defamation': he was claimed to have 'deliberately offended a group of people because of their race'. ${ }^{2}$ Additionally, the prosecution claimed that Wilders's statements amounted to incitement to hatred and/or discrimination on the grounds of race. ${ }^{3}$

\section{A particular group}

Wilders was already prosecuted on the basis of the same criminal provisions in 2011, and at the time was acquitted of all charges. A number of media and experts suggested that the same thing was quite likely to happen again. Legally speaking, however, the recent case differed from the earlier one in several ways.

* This opinion is based, in part, upon an essay published prior to the ruling in Belgian daily De Morgen: J. Vrielink, 'Hoe strafbaar is de 'minder Marokkanen'-uitspraak van Geert Wilders? Voor u ontward: de knopen in het proces-Wilders,' De Morgen, 26 November 2016.

1 District court of The Hague, 9 December 2016, ECLI:NL:RBDHA:2016:15014. For an English summary, see: 'Wilders found guilty of insulting a group and incitement to discrimination,' Press Release, 9 December 2016, www.rechtspraak.nl.

2 Art. 137c Dutch Criminal Code.

3 Art. 137d Dutch Criminal Code. 
In 2011, Wilders's statements primarily concerned Islam, ${ }^{4}$ while in the current case Wilders explicitly targeted a group of people, Moroccans. That distinction is important, since under Dutch legislation and prevailing case law you can hardly be convicted for the former but you can for the latter.

This has to do with the way in which the relevant criminal provisions are drafted - you either have to offend, or incite hatred or discrimination against a group of persons. Case law of the Dutch Supreme Court (Hoge Raad der Nederlanden) correspondingly requires that expressions 'unmistakably clearly refer to a particular group (...)'.5

After the murder of Theo van Gogh in 2004, someone hung a poster in his window that read: 'Stop the tumour that is Islam. Theo has died for us. Who will be next? Join the resistance now! National Alliance, we will not bow down to Allah. Join now'. That initially led to a conviction for group defamation. The Supreme Court overturned the conviction however, because the statement did not refer to Muslims as a (religious) group but only to Islam. Insulting a religion, the Supreme Court emphasised, does not constitute group defamation under Dutch criminal law, not even if the adherents' religious sentiments are hurt as a result. 'No criticism, however fierce, of views held by a group or of the behaviour of those belonging to the group comes within the scope of (...) the Dutch criminal code'. ${ }^{6}$

\section{'We want a heterosexual city'}

As far as speech targeting groups was concerned, it had also long remained unclear how far someone was allowed to go, legally speaking.

Traditionally, speech could be curtailed if it qualified as being 'unnecessarily offensive' (onnodig grievend). The problem with that 'criterion' is succinctly captured in the joke, 'I would like to say something unnecessarily offensive about you, but I am unable to think of anything unnecessary'. When exactly can something be regarded as 'unnecessarily offensive'?

In 2014, the Dutch Supreme Court shed more light on this issue, albeit not in favour of the freedom of expression. A local Amsterdam politician, Delano Felter, ${ }^{7}$ had said during a debate and in an interview that homosexuals are 'dirty men' with 'sexual deviations, who need to be actively opposed and controlled by heterosexuals'. His solution? We have to 'throw those people out', because 'we want a heterosexual city'.

4 Including his film Fitna, statements likening Islam to Nazism, and the Koran to Mein Kampf. See critically: Esther H. Janssen and Aernout J. Nieuwenhuis, 'Freedom of expression and hate speech on account of religion and race in the Wilders trial. An analysis of the 'trial of the century', Nederlands tijdschrift voor mensenrechten 2 (2012): 177-207.

5 Supreme Court, 10 March 2009, ECLI:NL:HR:2009:BF0655.

6 Ibid.

7 At the time Felter was the leader of a fringe political party: the Modern Republican Party (Republikeinse Moderne Partij) (now defunct). 
Initially, Felter was acquitted by the Amsterdam court of appeal. ${ }^{8}$ The court stressed that politicians are entitled to 'a wider freedom of speech' as compared to non-politicians. Referring to case law by the European Court of Human Rights (ECtHR), ${ }^{9}$ the court of appeal claimed there was little scope under Article $10 \S 2$ of the European Convention on Human Rights (ECHR) for restrictions on free speech in the area of political speech. The court of appeal went so far as to say that even if Felter's statements fulfilled all basic requirements for a conviction for incitement to hatred or group defamation, he was still free to express them in light of Article 10 ECHR. In other words, political free speech trumped criminal liability (in the given circumstances, at least).

The Supreme Court considered this as going too far. ${ }^{10}$ It confirmed that politicians must be able to freely comment on issues of public interest, even if in doing so they would 'shock, offend or disturb'. However, against this, the Supreme Court - also drawing on ECtHR case law - posited a greater responsibility on the part of politicians: they are not allowed to disseminate statements that 'conflict with the law and basic principles of a constitutional democracy'. Politicians, the court ruled, are no more warranted to overstep legal speech restrictions - including the ban on incitement to hatred, violence and discrimination - than private citizens. ${ }^{11}$

The Supreme Court reverted the case to the Amsterdam court of appeal for a retrial. The latter court applied the stricter criteria and convicted Felter. ${ }^{12}$ Moreover, the same criteria also rendered a successful prosecution of Wilders (even) more likely as the parallels were obvious. Take, for instance, the court of appeal's conclusion that Felter's statements amounted to incitement to discrimination vis-à-vis gay people, since said statements aimed to 'oppose [homosexuals'] presence in the Netherlands, or at least in Amsterdam' (fewer, fewer, fewer homosexuals, anyone?). The court of appeal furthermore ruled that the remarks were 'unnecessarily offensive' for the fact that they violated (or proposed to violate) basic democratic principles based on a group's sexual orientation (again, replace sexual orientation by ethnic background).

\section{A mere question?}

Wilders was acquitted for his statements on 12 March 2014, for which the court did not consider it to be established that Wilders had had the (conditional) intent

8 Court of appeal of Amsterdam, 11 March 2013, ECLI:NL:GHAMS:2013:BZ3787.

9 Most notably: ECtHR, 23 April 1992, Castells v. Spain; and ECtHR, 22 October 2007, Lindon v. France.

10 Supreme Court, 16 December 2014, ECLI:NL:HR:2014:3583.

11 Quite the contrary in fact: the Supreme Court de facto held politicians to a higher standard, in so far that it claimed that they should - additionally - avoid 'incitement to intolerance'. The judges in the Wilders case avoided application of this particular (controversial) aspect of the Supreme Court ruling.

12 Court of appeal of Amsterdam, 1 February 2016, ECLI:NL:GHAMS:2016:296. 
to merit a conviction for incitement to discrimination or hatred or group defamation. The court pointed out that there had not been any interaction with bystanders. Furthermore, witness testimony suggested Wilders's statement at the time to have been an off-the-cuff remark or slip of the tongue, which the court found plausible.

Concerning the second set of remarks, the question arose whether Wilders had actually said anything objectionable himself. Had he not, as he and his defence maintained, 'merely posed a question'? The court argued that this was a misrepresentation of what happened on 19 March 2014. Witness testimonies - not disputed or refuted by the defence - indicated that the public response had been carefully orchestrated, with the public being instructed on how to answer the questions Wilders would pose. Prior to Wilders's speech, a staff member had passed the tables, telling everyone: 'In a minute, you are supposed to chant 'Fewer, fewer!' you guys'. ${ }^{13}$ For this reason the court concluded that the eventual message was the result of a (planned) interplay between Wilders and the audience. ${ }^{14}$ Moreover, the public prosecution had anticipated this argument. It had charged Wilders not only with committing group defamation and incitement to discrimination, but also with its elicitation and with participation and complicity in its commission. Simply put, the prosecution cast its net wide enough to pre-empt the claim that Wilders had merely 'posed a question'.

Following that approach, the radical right-wing politician Hans Janmaat, leader of the Centre Democrats (Centrum Democraten), had been convicted in 1997 for participation in the commission of incitement to hatred, after having said during a public demonstration: 'We will abolish the multicultural society, as soon as we have the ability and the power". Not all that shocking, perhaps, but during the same demonstration others had chanted slogans such as 'Full is full' and 'Our own people first'. Precisely due to that heated atmosphere, and because of what the other protesters had shouted, Janmaat's statement could - in the view of the Arnhem court of appeal - 'not be understood otherwise than as being designed to remove (members of) ethnic minorities from Dutch society'. ${ }^{15}$ The Supreme Court upheld Janmaat's conviction ${ }^{16}$ and, moreover, dismissed a reconsideration request in $2003 .{ }^{17}$

14 In addition to this, one could point out that even Wilders himself did not actually limit himself to posing a question. As mentioned, he answered the crowd cheering 'Fewer, fewer' with 'Well, then we'll arrange that'.

15 Court of appeal of Arnhem, 29 December 1997.

16 Supreme Court, 18 May 1999, NJ 1999.

17 Supreme Court, 6 May 2003, ECLI:NL:HR:2003:AF7895. 


\section{A Moroccan race?}

Another central argument of those who believed Wilders ought to have been acquitted was a textualist one concerning the term 'race'. Most notably, professor Paul Cliteur, who was called as a witness in the trial, argued that Wilders's statements about 'Moroccans' concerned nationality. The Dutch hate speech provisions however only mention 'race'; and 'nationality' cannot be equated with race. 'From this we must infer', said Cliteur, 'that the Dutch legislator chose not to criminalize speech concerning nationality'. ${ }^{18}$

In response, the court rightly pointed out that the Dutch hate speech provisions are, in part and since 1971, an implementation of the UN International Convention on the Elimination of All Forms of Racial Discrimination (ICERD). The legislation's explanatory memorandum also explicitly refers to the ICERD on the meaning of 'race'. The Convention defines race as 'race, colour, descent, or national or ethnic origin'. ${ }^{19}$ This is also the way in which the concept has been interpreted and applied for decades in national and European case law. That being said, the Convention does exclude from its scope distinctions "between citizens and non-citizens' ${ }^{20}$ or issues pertaining to 'nationality, citizenship or naturalization'. ${ }^{21}$ However, the court argued that Wilders on 19 March 2014, in a manner that was clear and explicit to everyone, 'identified a group of fellow citizens by referring to their common origin', and used 'their nationality as an ethnic designation'. The term that was used, 'Moroccans', 'thus refers to the characteristics 'descent', 'national origin' and 'ethnic origin' as laid down in the ICERD and consequently concerns 'race' in the sense of the Dutch Criminal Code'.

One could add that while the Convention excludes nationality stricto sensu from its scope, the Convention also provides that distinctions on that basis may 'not discriminate against any particular nationality' (against Moroccans, for example). ${ }^{22}$

\section{Fewer criminal Moroccans?}

A literalist reading of the term 'race' was therefore rejected. But what about a nonliteralist reading of Wilders's statements? According to some, including Wilders himself, the call for 'fewer Moroccans' pertained only to a particular subset of Moroccans, i.e. criminal Moroccans. Party for Freedom supporter Henk Bres put it this way: 'Everyone knows perfectly well that [Wilders] meant people who cut off

18 Paul Cliteur, 'De harde tucht van de strafwet en het cultuurgoed dat we moeten verdedigen. Kanttekeningen gemaakt door getuige-deskundige Paul Cliteur tijdens het proces tegen Geert Wilders,' The Post Online, 3 November 2016.

19 Art. $1 \S 1$ ICERD.

20 Art. 1 § ICERD.

21 Art. $1 \S 3$ ICERD.

22 Art. $1 \S 3$ ICERD. Moreover, the exemptions concerning nationality apply to States Parties and not to individuals. 
people's heads in Amsterdam, and not your average hardworking Moroccan'. Legally speaking, such an argument is not in itself implausible. While assessing allegedly illegal utterances, courts tend to take into account the broader signifying context including the intended meaning of what was said, as well as how it was understood by the audience.

In this case however, the court found such an analysis not to yield an obstacle to Wilders's criminal liability. The judges pointed to the care with which the speech was prepared, to argue against a totum pro parte interpretation: testimony suggested that Wilders had knowingly and consciously chosen not to restrict his question to criminal Moroccans in order to generate maximum media-exposure. Furthermore, the court pointed to the rousing manner in which Wilders built up his speech. Wilders began by announcing that he wanted to get clear answers to three questions 'that define our party, the Party for Freedom'. His first question was: 'Do you want more or less European Union?' The room chanted, 'Less, less, less!' The second question, 'perhaps even more important', was: 'Do you want more or less Labour Party?' Again, the crowd responded: 'Less, less, less!!' with even more clapping and cheers. Finally, Wilders posed his 'Moroccans question', even pausing to say that he was 'actually not allowed to say it, because people will file criminal charges' ${ }^{23}$

All of this, the court argued, resulted in the clear and strong conclusion that was broadcasted directly into living rooms across the Netherlands'. The fact that Wilders subsequently stated that he had not wished to refer to all Moroccans did not, according to the court, make the message any less insulting. 'That message already came through loud and clear', the court added. The court concluded that Wilders's statements singled out 'an entire group of citizens without making any distinction'. Therefore, the statements could be regarded as being insulting for the entire group (group defamation) as well as amounting to incitement to discrimination. ${ }^{24}$

One could add to the court's analysis, in subordinate order, that the totum pro parte interpretation would still result in a distinction based on ethnic origin: even in that hypothesis only Moroccan criminals were targeted, while other (ethnic) groups are overrepresented in Dutch crime rates as well.

23 The ruling also points out that at the time Wilders knew that his earlier statements (on 12 March 2014) had already led to charges having been filed against him. The court considers this to imply Wilders 'had at least the conditional intent' concerning the insulting nature of his additional statements on 19 March 2014.

24 The district court found insufficient evidence for incitement to hatred, and Wilders was acquitted on that count. The court considered that hatred is 'an extreme emotion of deep disgust and hostility', and that incitement to hatred therefore required an 'enhancing element', whereby others are stirred up or called out to do something. Such an element was deemed absent from Wilders's rhetoric. 


\section{To offend, shock and disturb?}

Finally, some argued that if it were to come to a conviction, as it now has, the European Court of Human Rights would blow the whistle on the Netherlands. All things considered though, that seems highly unlikely.

A (if not the) core characteristic of the European Court is its aversion (bordering on allergy) of speech targeting ethnic and other minorities. It typically grants no scope whatsoever to speech that it regards as 'hate speech'. ${ }^{25}$ At the same time, the European Court applies a very broad (and rather fuzzy) definition of what constitutes 'hate speech'. Speech is unprotected if it fails to comply with highly abstract values of 'tolerance' and 'social peace'. This leaves very little room indeed for free speech, rendering the European Court's oft-repeated mantra - i.e. that Article 10 applies 'not only to 'information' or 'ideas' that are favourably received, but also to those that offend, shock, or disturb the State or any sector of the population' - all but meaningless in this specific area. ${ }^{26}$

National 'hate speech' convictions are virtually never considered a violation of the Convention ${ }^{27}$ and rarely even pass the admissibility stage. In the case of politicians engaging in hate speech in particular, there are literally no cases in which Article 10 was found to have been violated. ${ }^{28}$ The European Court basically provides a carte blanche to states parties in this regard. It grants domestic authorities a strikingly wide margin of appreciation, contrasting starkly with the way in which it treats other speech restrictions affecting politicians and the political debate. In short, the chances of Wilders being vindicated in Strasbourg are virtually non-existent.

25 In this context, the European Court attaches far-reaching implications to the fact that the drafters of the European Convention sought to establish an institutional framework based on democratic values in order to overcome extremism, and it therefore considers some (allegedly) 'anti-democratic' or 'radical' forms of expression contrary to the Convention.

26 See ECtHR 7 December 1976, no. 5493/72, Handyside v. the United Kingdom, $\S 49$ (since then repeated in countless cases).

27 Stefan Sottiaux and Jogchum Vrielink, 'Activism at the Admissibility Stage: A Threat to the Subsidiary Role of the European Court of Human Rights?' in Liber Amicorum Marc Bossuyt, ed. André Alen, Veronique Joosen, Riet Leysen and Willem Verrijdt (Cambridge: Intersentia, 2013), 663-679. A notable exception to this is the case of Jersild v. Denmark, decided 12 votes to 7, in which a journalist had been convicted for aiding and abetting in the dissemination of racially degrading or insulting speech, on account of him having interviewed members of a radical rightwing organization. This exception proves the rule however, to the extent that the Court did not protect the actual speech in this case but rather deemed the role that the journalist had played to be insufficient to warrant a criminal conviction, emphasising that Jersild had clearly dissociated himself from the persons he interviewed (ECtHR (GC) 23 September 1994, no. 15890/89, Jersild v. Denmark, §34).

28 Unless you were to count Perinçek v. Switzerland (ECtHR (GC), 15 October 2015, no. 27510/08), but that was a highly atypical case, concerning the denial of the Armenian genocide. The claims of all politicians convicted for engaging in more similar speech as Geert Wilders (e.g. Le Pen, Féret, Gündüz, Soulas), were flat-out rejected by the Court. 


\section{Political trial vs. the political process}

Given all of the above, convicting Wilders seems the most legally defensible decision the district court of The Hague could take. Given the provisions and the higher case law governing this case, the chances of an acquittal were much smaller than the probability of a conviction.

That is not to say I am enthusiastic about the trial or its outcome; in fact, quite the contrary.

To begin with, banning and prosecuting hate speech is about as productive as trying to attach a button to water. ${ }^{29}$ Positive results are hard to achieve, especially with politicians such as Wilders. The trial provided him with a lot of media attention, and his conviction enabled him to portray himself as a martyr for free speech $^{30}$ against the 'leftist elites' trying to muzzle him, causing people to feel sympathy for him who would otherwise not support his cause or ideas. Conversely, in (the unlikely) case Wilders is acquitted on appeal, he will emerge legitimized, and he and his supporters will feel warranted to engage in still more extreme speech.

On a more principled level, the prosecution is equally problematic. Yes, we should protect minorities against discrimination and inequality in the workplace, in education and in the criminal justice system. But we must, in the words of Ronald Dworkin, resist the temptation to 'try to intervene further upstream, by forbidding any expression of the attitudes or prejudices that we think nourish such unfairness or inequality'. ${ }^{31}$

The democratic majority should not have the right to impose its will upon whom it is forbidden to protest against the decision. Calling for discrimination is not the same as discrimination. Persons doing this must, in a democratic society governed by the rule of law, already accept that they will never be allowed to achieve their aims. Legally forcing them to remain silent about their wishes is a bridge too far and undermines 'our moral title to force such people to bow to the collective judgments that do make their way into the statute books'. ${ }^{32}$ All the more since in doing so you rob people of their (non-violent) means of protest, and push them and their beliefs into illegality.

But if that is my position, why do I, unlike others, not just argue for an acquittal? Because my objections derive from legal theory rather than (also) being legal in

29 See extensively on the (often counterproductive) empirical effects of prosecutions for (racist) hate speech: Jogchum Vrielink, Van haat gesproken? Een rechtsantropologisch onderzoek naar de bestrijding van rasgelateerde uitingsdelicten in België (Antwerp: Maklu, 2010).

30 Which is ironic, given how little respect Wilders himself has for other people's freedom of speech. Take for instance his calls for banning the Koran. Compare Ian Buruma, 'Totally tolerant, up to a point,' New York Times, 29 January 2009.

31 Ronald Dworkin, 'Foreword,' in Extreme Speech and Democracy, ed. Ivan Hare and James Weinstein (Oxford: Oxford University Press, 2009), viii. 
nature. ${ }^{33}$ It is impossible to deny that the existing Dutch hate speech legislation restricts free speech in a far-reaching manner, and changing that - if so desired falls to the legislature, not the courts. And it could be added that Parliament, even now, does not consider legislative change desirable. Shortly after the ruling, the Dutch Chamber of Representatives discussed a bill that could have avoided Wilders's conviction. A vast majority chose not to support the initiative. ${ }^{34}$

Geert Wilders claims that his is a political trial and a travesty of justice, asserting that even the legal system in North Korea is preferable to that of the Netherlands. It is undoubtedly true that the countless tortured political dissidents in North Korea will have nothing but pity for the fact that Wilders was brought before that horrendous district court in The Hague. ${ }^{35}$ More seriously, what judges decide is for the most part the result of what politics decided first, and that is how it should be. Here, the judges applied the law in the manner in which a democratically elected majority intended it to be applied; an acquittal would have been much more 'political'. In short, it is precisely because the Netherlands is not North Korea that Wilders is not above the law either, regardless of how unwise that law may be.

33 Not that there is a (sharp) divide between the two. However, given the statutes and precedents applicable to this case, there are limits to the arguments you can plausibly put forward. Put differently, the legal theory underlying the current Dutch legislation and case law departs fundamentally from the one I espouse.

34 See Christiaan Pelgrim, 'Tweede Kamer wil groepsbelediging niet uit de wet schrappen,' Nrc, 15 December 2016.

35 The court, moreover, limited itself to a declaration of guilt without imposing punishment (ex. Art. 9a Dutch Criminal Code). The court considered that the most important question in the case was whether Wilders had crossed a line; a simple guilty verdict already answered that question, and the court therewith found justice to have been done. 